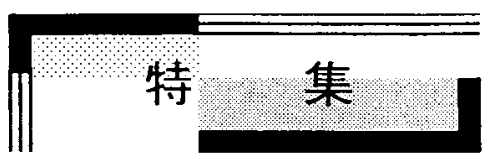

\title{
油濁対応における混相流体技術* （高粘度油中水型エマルジョンの管内輸送）
}

\author{
Multiphase Flow Techniques in Oil Spill Response \\ (Pipeline Flow of High-viscosity W/O emulsion)
}

\author{
藤田勇** \\ FUJITA Isamu
}

\begin{abstract}
Oil spill response requires multiphase flow techniques in various aspects. Among them, methods for treating water-in-oil emulsion, which is often formed when oil spills on the sea surface, are very important. W/O emulsion drastically increases its viscosity and makes oil recovery operation very difficult. This paper presents friction loss reduction techniques in a pipeline flow as well as rheological behavior of the emulsion. For friction reduction, water injection and chemical surfactant injection were experimentally studied. It was found that the both methods can reduce the friction loss to a considerable extent. They were applied to practical use for oil recovery vessels.
\end{abstract}

Keywords: Oil spill, W/O emulsion, Pipeline, Friction loss, Water injection, Chemical surfactant

\section{1. 緒 言}

近年タンカーからの油流出事故は減少傾向に ある。Fig.1に示す ITOPF の統計[1]に拠れば、1970 年代において流出量が 700t を越える比較的規模 の大きい油流出事故の発生件数は年平均 25.2 件 であったのに対し、2000 年代に入ってからは年 平均 3.6 件である。流出量ベースで見ても 1970 年代の年平均油流出量は 314,200t であるのに対 し、2000 年代は年平均 $24,000 t$ である。我が国に おいてもナホトカ号事故（約 6,400kl 流出）が発 生した 1997 年以降、幸いにして船舶からの大規 模な油流出事故を経験していない。しかしながら 大規模油流出事故の発生リスクは、世界的には 2007 年の韓国における Hebei Spirit 号の原油流出 にも見るように、依然として存在している。更に タンカー以外からの油流出として 2010 年のメキ シコ湾原油流出事故[1]は未だ記憶に新しい。

加えて、2011 年に発生した東日本大震災におい ては、各所で石油タンクが被災し、相当量の油が
流出した。震災による流出油は津波火災の要因と して考えられ[3]、また底泥への油の沈殿などが報 告されており[4]、平常時の油流出とは異なる様相 を示寸油流出のリスクを明らかにした。

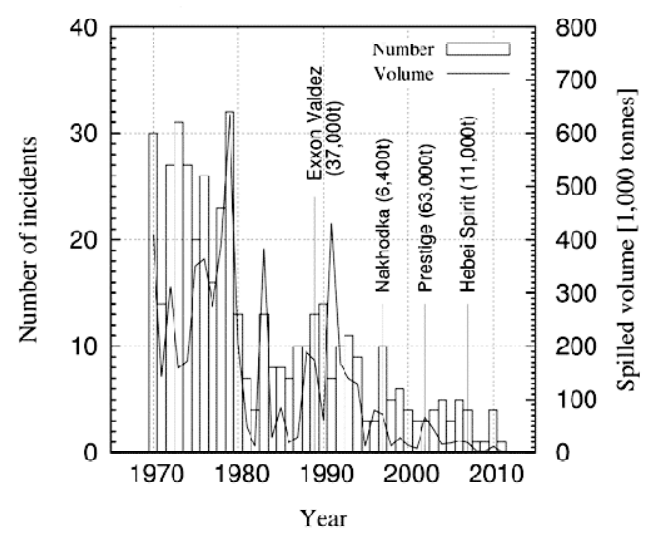

Fig.1 Oil spill trend from tankers.

* 2013.4.30 受付

** (独)港湾空港技術研究所 混相流体研究チーム・油濁対策研究チーム(併任) † 239-0826 横須賀市長瀬 3-1-1

TEL: (046)844-5065 FAX: (046)844-0575 E-mail: fujita@pari.go.jp 
洋上での流出油対応としては、油回収機を用い た回収、油処理剤を用いた分散処理、メキシコ湾 原油流出事故で用いられた現場焼却などが主な 方法であるが、技術開発の現場においては、混相 流体に関連する技術や知見を用いる場面が比較 的多い。例としては気液二相流による真空吸引式 油回収装置[5]や、高圧水エダクタや蒸気エジェク 夕を用いた油回収装置[6,7]あるいはエマルジョ ン分解[8]、水ジェットやバブルカーテンによる浮 遊油の漂流制御[9,10]、噴流を使った分散促進[11] などを挙げることができる。

本稿では油濁対策で用いられる混相流体技術 の一例として、液液混相流の応用である高粘度エ マルジョン化油の管内輸送における摩擦損失の 低減法に関して著者が行った一連の研究を紹介 寸る。具体的には注水による摩擦損失の低減、並 びに界面活性剤の添加によるエマルジョン分解 と管摩擦損失の低減への応用を报った。これらの 手法が効果があることはPeigne 等[12]により指摘 されていたことであるが、本研究では注水鬫滑に 関しては、気液二相流における整理法を応用して 最適注水量を明らかにしている。更に研究成果を 実際の油回収船の装備として実用化しているの で、その点についても触れる。

\section{2. エマルジョン化油の管摩擦損失の低減}

\section{1 流出油の風化}

海上に流出した油は時間の経過とともに、

Fig.2に示すように、蒸発、自然分散、溶解、沈 降、生物分解及びエマルジョンの形成などの風化 作用を受け[13]、それに伴って物理的な性状を変 化させる。各変化の進行状況は油種や気象海象条 件に強く依存する。その中で、洋上での油回収の 効率や分散処理の効果は、エマルジョン化の影響 を強く受ける。エマルジョン化では、主として波 浪などの攪找作用により、Photo 1 に示寸様に、 海水が小さな液滴として油の中に分散した状態 (W/O Emulsion) で取り込まれる。写真において 明るく見える部分が水であり、暗い部分が油の相 である。Fig.3は石油連盟がネット上で公開して いる流出油の性状変化データベース[14]をもとに 作成した冬期の荒れた海での C 重油と代表的な 原油である Arabian light の風化を示した図である が、時間の経過とともにエマルジョン化が進行し、 油の中に取り込まれる水の量が増加し膨潤する
とともに、粘度が飛躍的に増大寸ることが分かる。

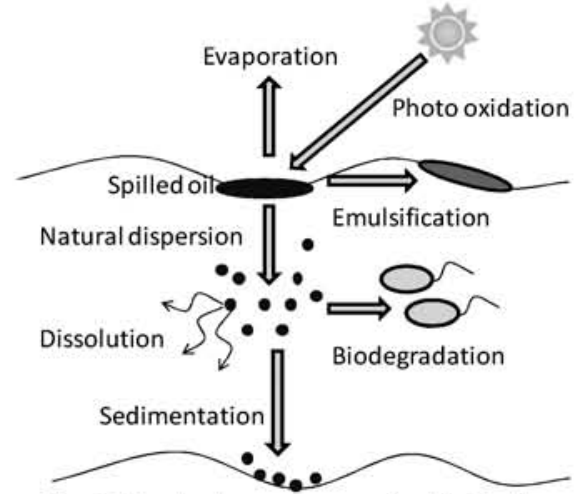

Fig.2 Weathering process of spilled oil.

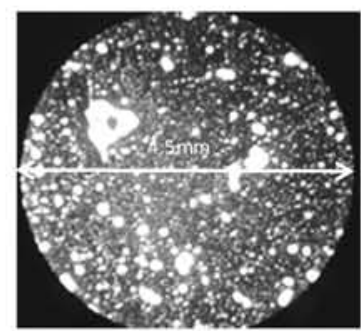

Photo 1 Microspcopic image of water-in-oil emulsion.

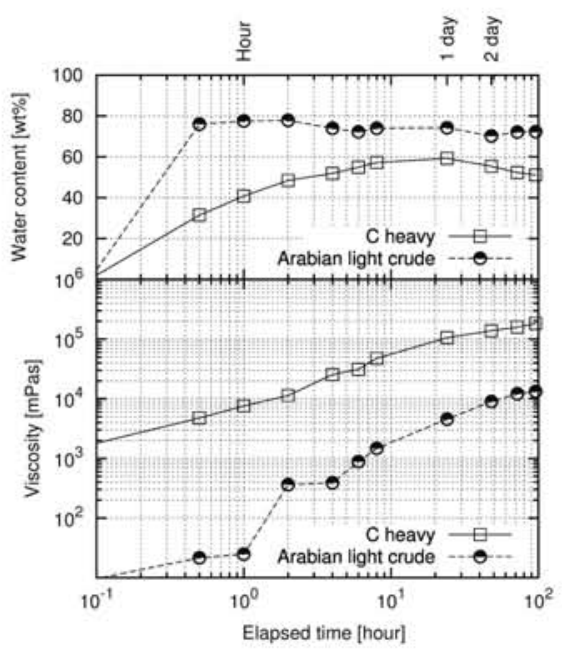

Fig. 3 Viscosity increase by emulsification.

1997 年に日本海で発生したナホトカ号による 油流出事故においても、流出油は $1,000,000 \mathrm{mPa} . \mathrm{s}$ を超すエマルジョンを形成したため、回収や移送 は困難を極めるものであった。多くの油回収機、 油回収船では配管による回収油の輸送行程が含 まれるため、そうした機器における高粘度油への 
対応が求められる。また、油処理剤による分散処 理においてもエマルジョン化により高粘度化し た油に対しては効果は小さくなる。目安として、 通常型の油処理剂の適用範囲が 2,000cSt 以下、高 粘度油用の D1128 型の油処理剂の適用範囲が 100,000cSt 以下と言われている[15]。

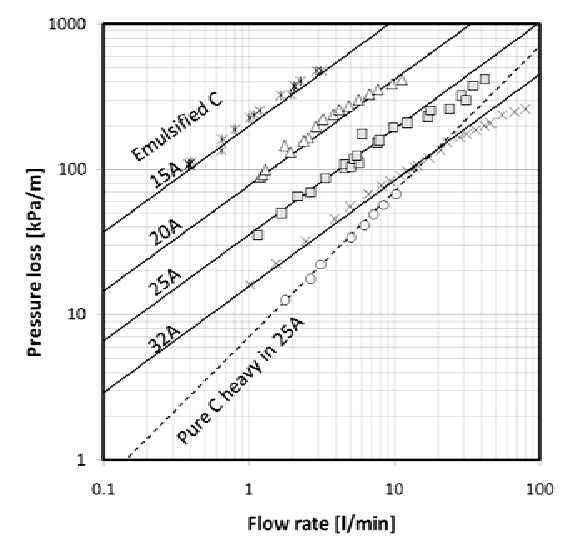

Fig.4 Friction loss measurements of flow of W/O emulsion in hozirontal pipes.

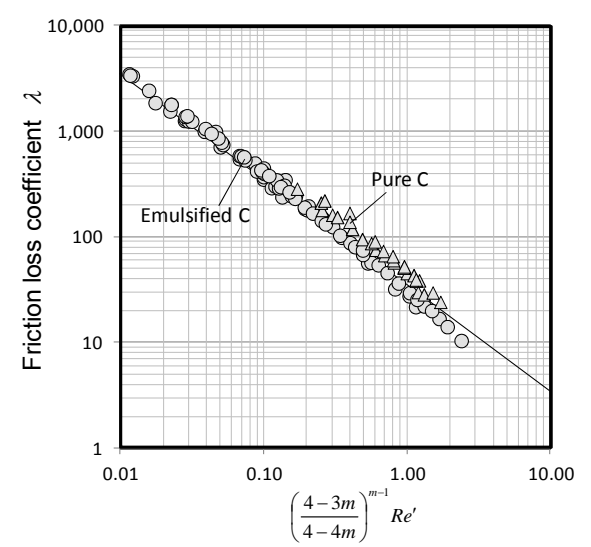

Fig.5 Correlation between friction loss coefficient and modified Reynolds number.

\section{2 重油エマルジョンの管内流動特性}

前節においては、エマルジョンを形成した油は 粘度が増大寸ると書いたが、厳密にはエマルジョ ン化によりニュートン流体から非ニュートン流 体へとレオロジー的な変化が生じる。ここではエ マルジョン化した C 重油の管内流摩擦損失の測 定結果を示す。市販のC 重油に等量の水を加え自 由水が無くるまで数時間攪拌し調製したエマル ジョン化油の水平直管における摩擦損失を Fig.4 に示す。両対数グラフにおいて、生の C 重油は傾
きが 1 の直線に乗り、層流における摩擦損失の式 64/Re が当てはまる。一方でエマルジョン化した 油の摩擦損失は流量の増加に対して傾きは 1 よ り小さくなり擬塑性流体的に振る舞うことがわ かる。重油エマルジョンの管内摩擦損失を $\Delta P=\frac{\lambda}{d} \frac{\rho}{2} U_{\text {avg }}^{2}$ の形で整理する。エマルジョン化 油の粘度特性を

$$
\tau=\tau_{r}\left(\frac{\varepsilon}{\varepsilon_{r}}\right)^{1-m}
$$

と仮定すると円管内の層流の壁面剪断力は、

$$
\tau_{w}=\frac{\tau_{r}}{\varepsilon_{r}^{1-m}}\left(\frac{d U}{d r}\right)^{1-m}=\frac{\tau_{r}}{\varepsilon_{r}^{1-m}}\left(\frac{4-3 m}{1-m}\right)^{1-m}\left(\frac{U_{\text {avg }}}{r_{w}}\right)^{1-m}
$$

と表すことができる。管摩擦損失と壁面剪断力は は $\Delta P=\frac{2 \tau_{w}}{r_{w}}$ の関係にあるので、摩擦損失係数 $\lambda$ は、

$$
\lambda=\left(\frac{4-3 m}{4-4 m}\right)^{1-m} \frac{64}{R e^{\prime}}
$$

となる。ここで、Re' は擬塑性流体における等価 的なレイノルズ数として、

$$
R e^{\prime}=\operatorname{Re}\left(\frac{U_{\text {avg }}}{\varepsilon_{r} d}\right)^{m}
$$

で定義している。 $\tau_{r}=50,000 \mathrm{mPa} . \mathrm{s} 、 \varepsilon_{r}=1.0 \mathrm{~s}^{-1} 、 m=0.27$ を仮定して実験結果を整理したものを Fig.5に示 す。測定值は生のC 重油も含めてマイナス一乗の 線に乗っており、整理式が妥当なことがわかる。

\section{3 注水による摩擦損失低減法}

エマルジョン化した油を管路により移送する 場合には摩擦損失を低減することが必要になる。 少量の水を添加すると Fig.6 に示すような油のコ アの周りを水が環状に取り巻いた CAF（Core Annular Flow）が形成され粘度の小さい環状水が 剪断変形を主として受け持つので管摩擦損失を 低減することができる。油-水系における CAF の 形成は古くから知られており [16]、その後石油産 業界で、高粘度油の生産井における潤滑方法とし て提案されている[17]。更に流出油回収移送時へ の応用を目的とした研究も行われている[18,19]。 著者においても、油回収船への応用を念頭に実験 による検討を行った[20]。 


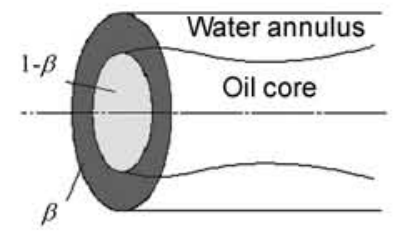

Fig.6 Schematic of CAF (Core Annular Flow).

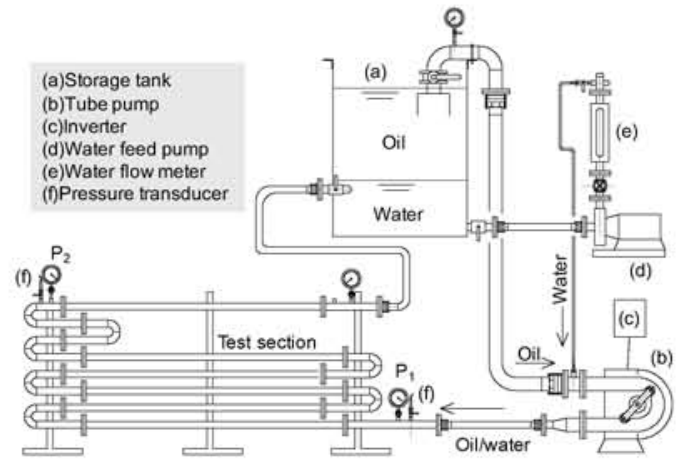

Fig.7 Schematic of experimental setup for CAF.

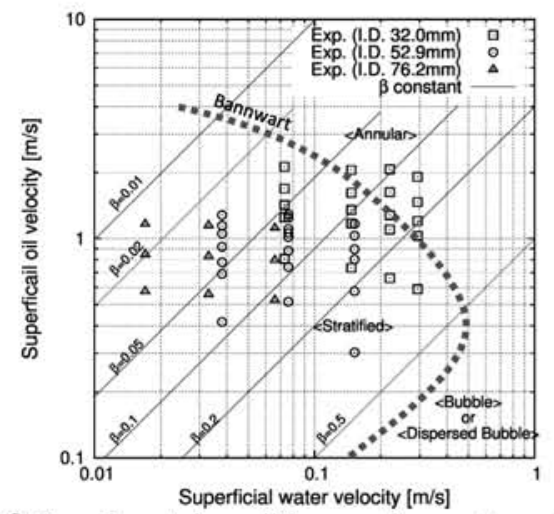

Fig.8 Experimental conditions on flow pattern chart.

Fig.7 に示寸装置を用いて、水の添加量に対す る摩擦損失の低減効果を実験的に検証した。3 種 類の内径が異なる円管にチューブポンプにより エマルジョン化油を流し、配管途中の枝管より水 を添加した。エマルジョン化油は、C 重油と水を 混ぜて調製した含水率は67.5\%のものを使用した。 エマルジョン化油の粘度は $39,000 \mathrm{mPa} . \mathrm{s}$ (ずり速 度 $1.0 \mathrm{~s}^{-1}$ の時) であった。実験条件をFig. 8 に示 す。横軸は添加水の見かけの流速、縦軸は油の見 かけの流速である。破線はBannwart[21]による流 動様式の整理である。 める水の割合として

$$
\beta=\frac{Q_{w}}{Q_{c}+Q_{w}}
$$

で定義した。

実験ではFig.7 に示すような管路の曲がり部の 影響は大きく無く、水の注入により圧力損失の低 下が計測された。実験結果の整理モデルとして気 液二相流で用いられるボイド率を用いる方法を 援用した。Lottes 等[22]は気液二相流の管摩擦損 失に対して、

$$
\frac{\Delta P_{F}}{\Delta P_{W}}=(1-\alpha)^{-m}
$$

という式を提案している。本研究では1- $\alpha$ の液ホ ールドアップの部分を注水率 $\beta$ で読み替えて

$$
\frac{\Delta P_{F}}{\Delta P_{W}}=\beta^{-m}
$$

というモデルを導入した。 $m$ の值はLottes は 2 を 用いている。気液系における他の研究においては 常圧の空気一水系の測定から $m=1.4 \sim 2.25$ が得ら れたという報告や、垂直管の液流速が速い範囲に 対しては気液二相流の測定では $m=1.75$ が良く成 立するという報告がある[23]。理論的には、油と 水が同じ物性を持っていると仮定する (即ち単相 流と仮定）し、摩擦損失係数として Blasius 式を 用いると $m$ の值は 1.75 となる。一方油が剛体と 同じように振る舞うと仮定すると $m$ は 2.0 となる。 式（7）を用いて実験結果を整理した。 $\beta$ と摩擦 損失比の関係をFig.9に示す。

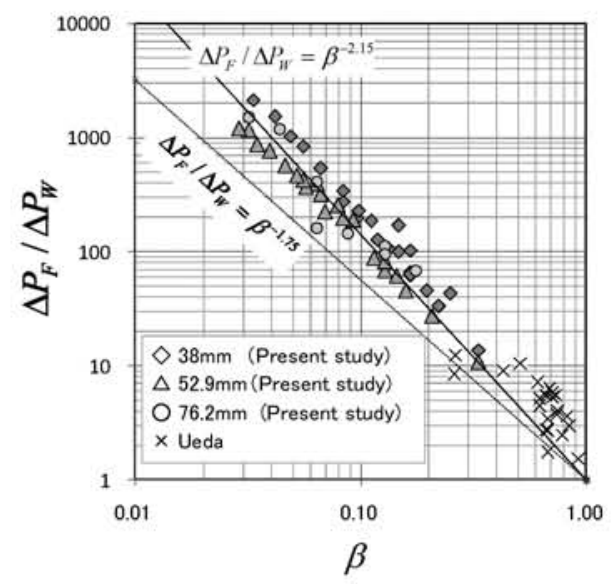

Fig. 9 Correlation between $\beta$ and $\Delta P_{F} \Delta P_{W}$. 


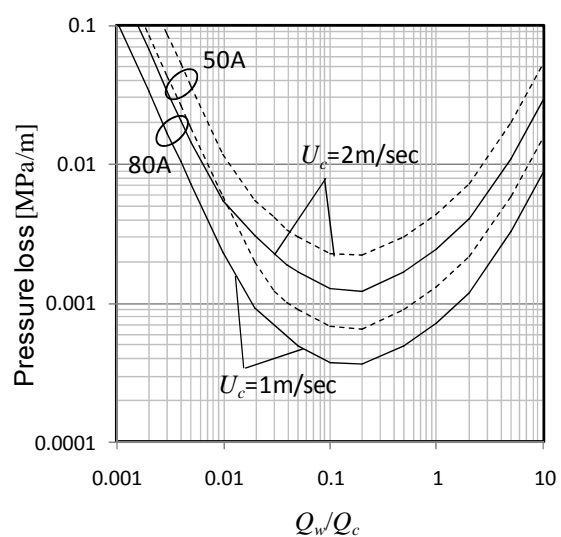

Fig.10 Optimum water addition rate.

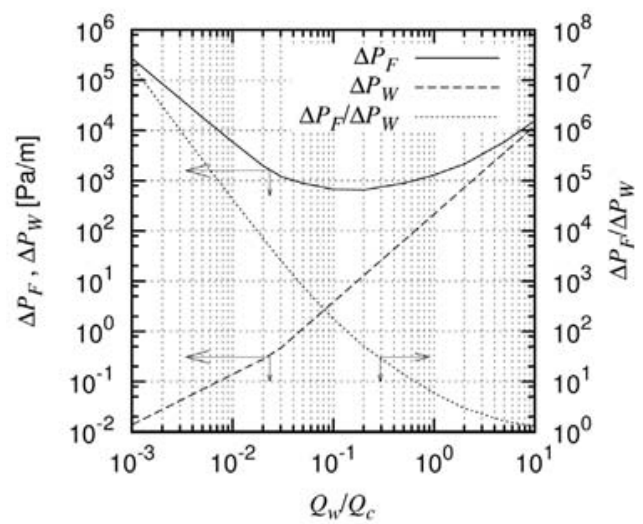

Fig.11 Factors affecting friction loss of emulsion flow.

図中の X印は Ueda[17]によるものである。 $m$ とし て 2.15 を仮定すると摩擦損失と $\beta$ の間に良い相関 が得られた。このモデルを用いて最適な水の添加 量を求めた。Fig.10に示すように、エマルジョン 化油に対して $10 \%$ 程度の水を添加した場合が最 も摩擦損失を小さくできるという結果になった。 この様に注水量に最適値が存在するのは、Fig.11 に示すように、水の添加量が小さい場合には $\beta$ 合 小さいので $\Delta P_{F} / \Delta P_{W}$ が大きく、逆に水の添加量 を適正值を越えて大きくした場合には、 $\Delta P_{F} / \Delta$ $P_{W}$ は小さいが、一方で水の見かけの圧力損失 $\Delta$ $P_{W}$ 自体が大きくなるので $\Delta P_{F}$ は増大寸ることに よる。

\section{4 薬剤添加による摩擦損失の低減法}

油濁防除においては回収の他に分散処理も行 われる。分散処理では油処理剂を浮遊油に対して 散布し、海中に油を分散希釈し無害化を図るもの である。油処理剤は界面活性剤を含んでおり、こ
うした薬剤をエマルジョン化油の管路輸送にお ける摩擦損失低減用の添加剂としても用いるこ とができる。

予備実験としてエマルジョン化油に界面活性 剤を少量添加した場合のエマルジョンの分解特 性を紹介する[24]。B 型粘度計にエマルジョン化 油を入れてずり速度を与えた場合の剪断応力を 測定する。あるタイミングで界面活性剂を少量滴 下し、その後の剪断応力の時間変化を計測した。 結果をFig.12 に示す。界面活性剂を添加すると、 時間の経過に伴って、エマルジョンが分解され、 剪断応力が減少することがわかる。減少の割合は 剪断速度が大きい程大きい。剪断応力の時間変化 を

$$
\frac{\tau}{\tau_{0}}=\exp \left(-\frac{t}{t_{0}}\right)
$$

で表して解析を行うと、時定数 $t_{0}$ はずり速度の二 乗に反比例することがわかる。このことは界面活 性剂を添加した際のエマルジョンの分解速度が 攪找に伴う散逸エネルギーに比例することを意 味していると考えられる。この現象を使うと Fig.13 に示すロータリー型の攪挥装置を用いて 配管による移送途中でエマルジョンを分解する ことができる。処理されたエマルジョンは暫く静 置するとPhoto 2 に示すように油と水に分離し、 分離した油相の粘度はエマルジョンを形成する 前の油に近いものに戻る。

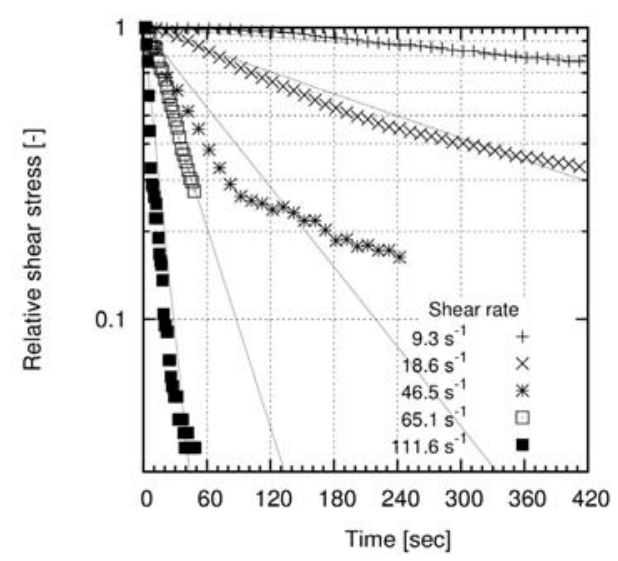

Fig.12 Emulsion breaking by surfactant addition. 


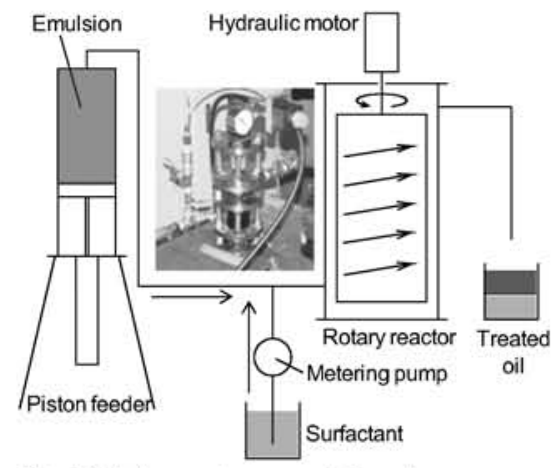

Fig. 13 Inline rotary emulsion decomposer.

(a)

(b) (c)

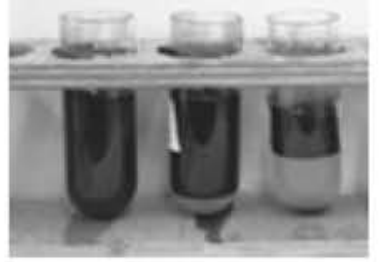

Photo 2 Demulsification by rotary decomposer, (a)no treatment, (b)only surfactant added, (c)surfactant added and agitated by the device.

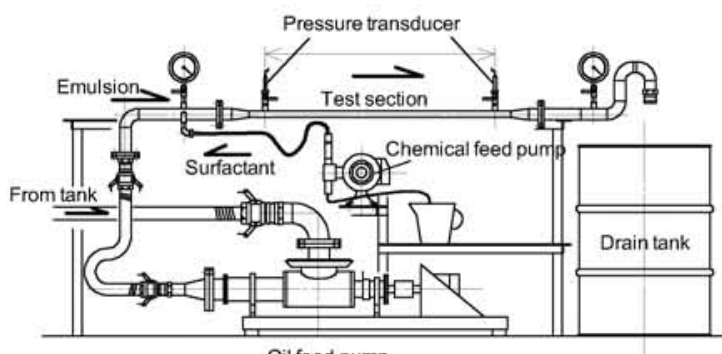

Fig.14 Schematic of experimental setup for friction reduction by surfactant addition.

完全なエマルジョン分解を行わず、管路におけ る摩擦抵抗を低減するだけで良い場合は強制的 な覧拌を行わなくてもよく、少量の界面活性郕を 管路に注入することで摩擦を低減することがで きる。Fig.14 に示す装置を用いてエマルジョン化 油の管内流に界面活性剤を添加する実験を実施 した[25]。実験では、薬剤の添加量を一定に保ち、 油の流量を徐々に増加させて管路で発生する摩 擦損失を測定した。添加薬剤としてはスルホコハ ク酸ジェチルヘキシルナトリウム溶液、モノラウ リン酸ソルビタン溶液、一般型油処理剤、セルフ
ミキシング型油処理剤等を用いた。例としてモ， ラウリン酸ソルビタン溶液を添加した場合の摩 擦損失を Fig.15 に示す。エマルジョン化油に対 して薬剤を添加した場合、摩擦損失が減少するこ とがわかる。他の薬剤を用いた場合も、程度に差 はみられるものの、いづれの場合も摩擦損失は低 下した。一般型油処理剤の場合の薬剤濃度と摩擦 損失の低減率との関係を Fig.16に示す。1\%の添 加で摩擦損失を $1 / 10$ に減らすことができること がわかる。界面活性剤の添加による摩擦損失の低 減のメカニズムは前節の CAF とは異なる。界面 活性剤の代わりに水を注入した場合、十分な量の 水添加ではほぼ CAF 理論が予測する摩擦損失の 低下が見られたが、界面活性剤の添加量と同程度 の水添加では圧力の降下現象は見られなかった。 このことは薬剤の注入においては、単なる CAF の形成ではなく、界面活性剂によるエマルジョン 分解が管壁近傍において発生していることを示 すものと考えられる。

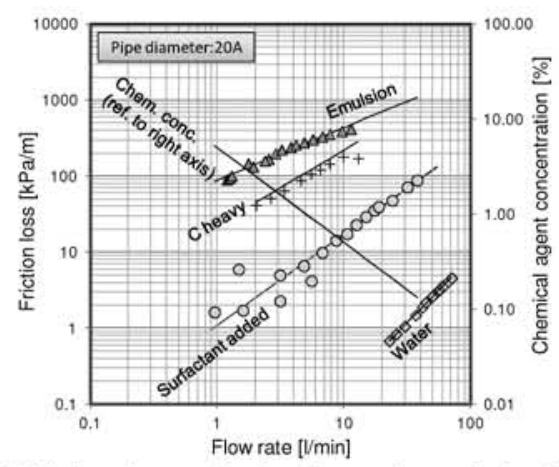

Fig.15 Friction loss reduction by surfactant injection. Surfactant:Sorbitan cocorate, 5 times diluted with $\mathrm{EtOH}$.

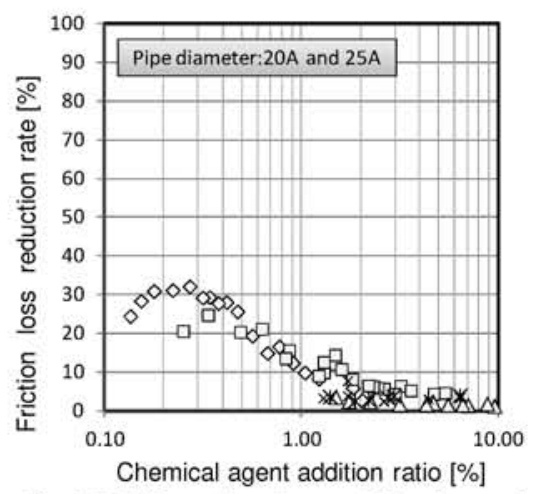

Fig.16 Effect of surfactant injection ratio. Surfactant:oil dispersant AB-3000. 


\section{3. 油回収船への適用}

前章で述べた管摩擦損失の低減手法は実際の 油回収船における装備として活用されている。注 水による方法は大型油回収船「白山」における回 収油の船外排送システムの一部として機関排熱 を利用したタンク内バルクヒーティングと組み 合わせて実用化されている[26]。一方、薬剤添加 による方法は、浮遊堰式油回収機を搭載した油回 収船の支援装置として実用化されている。ここで は薬剤添加法の実装について紹介寸る。浮遊堰式 油回収装置の構造をFig.17 に示す。

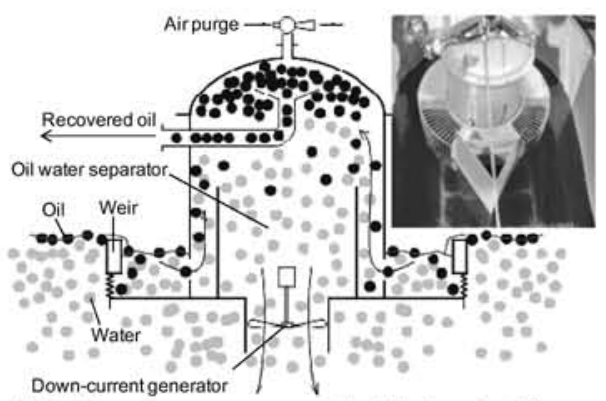

Fig.17 Oil water separator embedded weir skimmer.

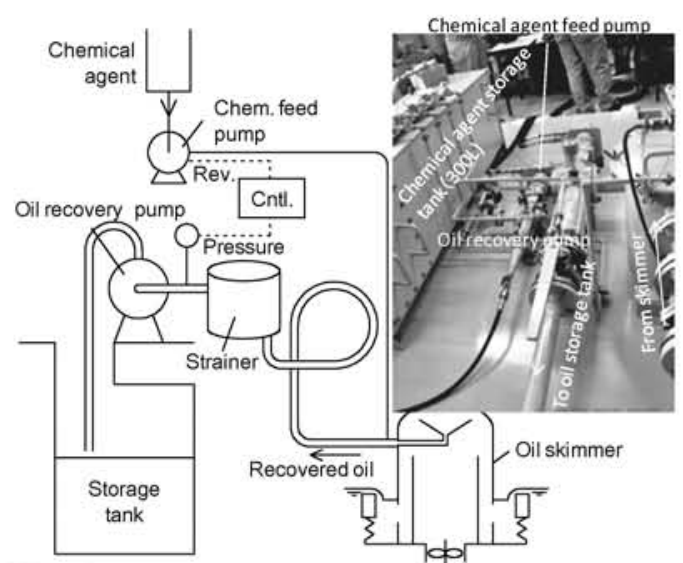

Fig.18 Surfactant injection system for oil recovery vessel.

この装置の大きな特徵はいわゆる殹式の油回 収装置に釣り鐘状の油水分離器を組み合わせた 点である。油水分離器内部では重力分離により油 を容器の上方に集め、下部からはプロペラにより 自由水を強制排水する。この様な仕組みにより、 自由水をほとんど含まない高濃度の油回収を実 現している[27]。反面、高粘度のエマルジョン油 を回収した場合、管路閉塞を起こし易い弱点を持
つ。その為、管路内の摩擦損失を低減させる必要 があり、Fig.18に示す薬剤注入システムを増設す ることで問題の解決を図ることとなった。システ ムでは油回収ポンプの吸い込み圧力に応じて薬 剤注入量を調整するフィードバック制御を行っ ている。Photo 3 に示寸国土交通省近畿地方整備 局の新造環境整備船「クリーンはりま」の油回収 装置でも採用されている。

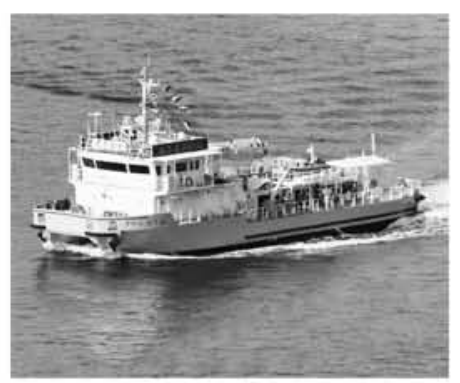

Photo 3 New oil recovery vessel "Clean Harima".

\section{4. 結 言}

海上流出油一の対応技術の内、混相流体的な話 題として、エマルジョン化した油の管摩擦損失低 減方法についての実験を主体とした研究と、実船 での成果の活用を紹介した。油濁対策においては、 序論でも述べたように、混相流体に関連する技術 を必要としており、今後も更なる研究開発が求め られているところである。

\section{Nomenclature}

$\Delta P_{F} \quad$ : pressure drop of multiphase flow $\quad[\mathrm{Pa} / \mathrm{m}]$

$\Delta P_{W} \quad$ : pressure drop of water flow $\quad[\mathrm{Pa} / \mathrm{m}]$

d : diameter [m]

$m$ : rheological parameter [-]

$Q_{c} \quad:$ oil flow rate $\quad\left[\mathrm{m}^{3} / \mathrm{s}\right]$

$Q_{w} \quad$ : water flow rate $\quad\left[\mathrm{m}^{3} / \mathrm{s}\right]$

$r$ : radius [m]

Re : Reynolds number [-]

$R e^{\prime} \quad$ : modified Reynold number [-]

$t$ : time [sec]

$t_{0} \quad$ : time constant for emulsion breaking [sec]

$U$ : velocity $[\mathrm{m} / \mathrm{s}]$

$U_{\text {avg }}:$ averaged velocity $\quad[\mathrm{m} / \mathrm{s}]$

\section{Greek letters}

$\alpha \quad$ : void fraction 
$\beta \quad$ : water fraction $\quad[-]$

$\varepsilon \quad$ : shear rate $\quad[1 / \mathrm{s}]$

$\varepsilon_{r} \quad:$ shear rate at reference state $\quad[1 / \mathrm{s}]$

$\lambda \quad$ : friction coefficient $[-]$

$\rho \quad$ : density $\quad\left[\mathrm{kg} / \mathrm{m}^{3}\right]$

$\tau \quad:$ shear stress $\quad[\mathrm{Pa}]$

$\tau_{r} \quad:$ shear stress at reference state $\quad[\mathrm{Pa}]$

$\tau_{w} \quad:$ wall shear stress $\quad[\mathrm{Pa}]$

$\tau_{0} \quad$ : initial shear stress $\quad[\mathrm{Pa}]$

\section{参考文献}

[1] Huijer, K., Trends in Oil Spills from Tanker Ships 1995-2004, 28th Arctic and Marine Oilspill Program (AMOP) Technical Seminar, 7-9, June 2005, Calgary, Canada (2005).

[2] National Commission on the BP Deepwater Horizon Oil Spill and Offshore Drilling, Deep Water-The Gulf Oil Disaster and the Future of Offshore Drilling-Report to the President, Jan. (2011).

[3] Shinohara, M., Ogawa, Y. and Matsushima, S., Fires in Kesennuma Following the 2011 Great East Japan Earthquake, Bulletin of Japan Association for Fire Science and Engineering, Vol. 62(3), 16-20 (2012).

[4] Takahashi, S., et al., Urgent Survey for 2011 Great East Japan Earthquake and Tsunami Disaster in Ports and Coasts, Technical Note of the Port and Airport Research Institute, No.1231, 75-78 (2011).

[5] Fujita, I., et al., An Onboard Air Conveyer Oil Skimmer, Conference Publication of Oceans 2006, 1-6(CDROM) (2006).

[6] Fudo, M., The Development of a Handy Oil Skimmer, Sea Technology Magazine, June (2005).

[7] Fujita, I., et al., A New Oil Recovery System using Steam-driven Ejector, Conference Publication of Oceans 2007-Europe, 1-6(CDROM) (2007).

[8] Fujita, I., et al., Steam Jet Pump for Oil Recovery and Reformation, IOSC, Vol. 2005, 589-593 (2005).

[9] Nash, J. H. and Johnson, M. G., Coherent, Plunging Water Jets for Oil Spill Control, IOSC,Vol.1981,655-660 (1981).

[10] Eidnes, G., et al., Containing Oil Spills by Use of Air Bubbles, ISOPE (2013).

[11] Iwasaki, A., et al., Dispersion of Spilled Heavy Oil by Water Jet, JSME Fluid Eng. Div. Conference Publication, 1-4(CDROM) (2006).

[12] Peigne, G. and Cessou, M., Improving the Pumping of Viscous Oil by the Use of Demulsifiers or by an Annular Water Injection,
IOSC, Vol.1989,175-180 (1989).

[13] Fingas, M., The Basics of Oil Spill Cleanup 2nd edition, 39-50, CRC Press (2000).

[14] PAJ, Database of Property Change of Spilled Oil (in Japanese), http://www.pcs.gr.jp/doc/ keijihenka/jdatabase.html.

[15]Marine Disaster Prevention Center, Oil Spill Response Manual, First edition (in Japanese), p.40 (2000).

[16] Charles, M., et al., The Horizontal Pipeline Flow of Equal Density Oil-Water Mixture, Can. J. Chem. Eng., Vol.39(1), 27-36 (1961).

[17] Prada, V., et al., Modeling of Vertical Core Annular Flows and Application to Heavy Oil Production, ETCE2000 \& OMAE2000 Joint conference, CD-ROM, February 14-17, New Orleans (2000).

[18] Ueda, K. and Yamanouchi, H., Friction Loss Reduction in Pipeline Flow of High Viscosity Recovered Oil (in Japanese), 73rd JIME conference, 103-104 (2005).

[19] Asakura, K., et al., Pressure Loss of Water-Oil Core Annular Flow, Proc. of Jpn. Soc. Mech. Eng. (Fluid Eng.), September 9-10, 483-486 (2000).

[20] Fujita, I., et al., Friction Loss Reduction by Water Injection in Pipe Line Flow of Heavy Oil Emulsion, Annual Journal of Civil Engineering in the Ocean, JSCE, Vol.25, 1023-1028 (2009).

[21] Bannwart, A.C., et al., Flow Patterns in Heavy Crude Oil-Water Flow, J. Energy Resource Technology, Vol. 126(3), 184-189 (2004).

[22] Lottes, P. A. and Flinn, W. S., A Method of Analysis of Natural Circulation Boiling Systems, Nucl. Sci. Eng., Vol.1, 420 (1956).

[23] Ueda, T., Gas-Liquid Two Phase Flow, 34-35, Yokendo (1981).

[24] Fujita, I., et al., Study on Emulsion Breaking of Spilled Oil, Proc. of $19^{\text {th }}$ JASNAOE Ocean Engineering Symposium, Oct. 18-20, CD-ROM (2006).

[25] Fujita, I., Friction Loss Control of Heavy Oil Emulsion in Pipe Line by Surface Active Agents, J. Civil Eng. B-3, JSCE, Vol.27(2), I_1027-1032 (2011).

[26] Development of Advanced Offloading System of Recovered Oil for Large Scale Oil Recovery Vessel "Hakusan" (in Japanese), Technical Report of Niigata Research and Engineering Office for Port and Airport, No.10, 119-124 (2010).

[27] Fujita, I., et al., A New Weir Skimmer Test for an Oil Recovery Vessel Dr.Kaiyo, Conference Publication of OCEANS 2008 (CD-ROM), April 8-11, 1-5 (2008). 